\title{
Yeni Medya Haberlerinde Kentsel Mekân ve Çocuk
}

\author{
DOI: $10.26466 /$ opus.666726
}

\section{Zehra Kurt *}

* Dr. Arş. Gör, Hatay Mustafa Kemal Üni., İI..B.F, Siyaset Bilimi ve Kamu Yön. Böl., Hatay/Türkiye E-Posta: zehraakurt@gmail.com

ORCID: $\underline{0000-0001-7252-6501}$

Öz

Çocuklarm kentsel mekânlar içerisindeki varlığı, son zamanlarda sosyoloji, kamu yönetimi ve iletişim gibi farklı alanlarda üzerine çalışılan bir konudur. Bu çalışma alanları, çocukların kent içerisindeki konumlarını toplumsal açıdan irdelemekte ve kentsel mekânları aktif kullanımlarını artırmaya yönelik çabalar içerisine girmektedir. Günümüzde çocukların kent içerisinde sokak, park ve yeşil alan gibi kamusal alanlarda geçirdikleri zamanın geçmişe göre azaldığı görülmektedir. Ailelerin güvenlik kaygısl, yeni iletişim teknolojilerinin çocuklar evde zaman geçirmeye yönlendirmesi ve kent içerisinde çocukların gelişimine uygun mekânların eksiklĭgi, bu durumun başlıca sebepleri arasında sayılabilir. $\mathrm{Bu}$ doğrultuda çalışmanın konusu, çocukların kentsel mekânlardaki varlığının yeni medya haberlerindeki yansımasıdır. Çocukların kentsel mekânlardaki varlığıyla kastedilen onların kamusal alanları kullanım düzeyleridir. Çalışmanın ana sorunsal, çocukların kent içerisinde ne tür sorunlar yaşadıklarını ve karşılaştıkları tehditleri ortaya koyabilmektir. Bu yüzden gündelik hayattaki toplumsal olay ve durumlar hakkında önemli ipuçları veren yeni medya haberleri analiz edilmiştir. Çalışmanın amacl, yeni medya haberlerindeki "kentsel mekân ve çocuk ilişkisine" yönelik söylemleri irdelemek olduğundan konuyla ilgili haber metinleri "eleştirel söylem analizi" yöntemiyle çözümlenmiştir. Çözümlemelerden elde edilen veriler, çocukların kent içerisindeki kamusal alanları kullanırken yaşamlarını tehdit eden sorunlarla karşılaştıklarını göstermektedir.

Anahtar Kelimeler: Kentsel Mekân, Çocuk, Yeni Medya, Eleştirel Söylem Analizi, 


\title{
Urban Space and Child in New Media News
}

\begin{abstract}
The existence of children in urban spaces has recently been studied in different fields such as sociology, public administration and communication. These fields of study examine the social position of children in the city and make efforts to increase the active use of urban spaces. Today, it is seen that the time spent by children in public spaces such as streets, parks and green spaces in the city is decreased compared to the past. The main reasons for this are the families' security concerns, the new communication technologies that direct children to spend time at home and the lack of suitable places for children's development in the city. Accordingly, the subject of the study is the reflection of the existence of children in urban spaces in the new media news. The presence of children in urban spaces means their level of use in public spaces. The main problem of the study is to reveal what kind of problems children face in the city and the threats they face. For this reason, new media news that provide important clues about social events and situations in daily life were analyzed. Since the aim of the study was to examine the discourses on the media "urban space and child relationship" in the new media news, news texts on the subject were analyzed with the method of "critical discourse analysis". The data obtained from the analyzes show that children face problems threatening their lives while using public spaces in the city.
\end{abstract}

Keywords: Urban Space, Child, New Media, Critical Discourse Analysis 


\section{Giriş}

Kentsel mekân, insanların gündelik hayat içerisinde farklı ihtiyaç ve motivasyonlarını gidermek için kullandıkları yerler olmakla birlikte toplumsallığın/sosyalleşmenin gerçekleştiği alanlar olarak da değerlendirilmektedir. Her yaş grubundan insanın kentsel mekânları güvenli ve verimli kullanabilmeleri için bazı temel çözümlemelere dikkat edilmesi gerekmektedir. Örneğin Henri Lefebvre'nin "kent hakkı" çözümlemesi bunlardan biridir. Lefebvre'ye göre kentsel mekândan yararlanma hakk1, belli bir ekonomi-politik gruba değil kentte yaşayan herkese aittir. Kentsel mekânı kullanan yaş gruplarının önemli bir çoğunluğunu da çocuklar oluşturmaktadır.

Kentsel mekân ve çocuk ilişkisi, son zamanlarda ilgi çeken ve üzerine farklı araştırmaların yapıldığı bir konudur. Özellikle Birleşmiş Milletler tarafından imzalanan Çocuk Hakları Sözleşmesi' nde çocuğun “yaşama, gelişme ve sosyal yaşama katılma hakları"na ait maddelerin bulunması, bu konuyu önemli kılan unsurlardan biridir. Çocuğun toplumla etkileşim halinde ve güvenli bir şekilde yaşayabilmesi, kentsel mekânı kullanım olanaklarının iyileştirilmesiyle mümkün görünmektedir. Lucio, J. ve I'Anson, "etkileşimci toplum" çözümlemesiyle çocukların kentin bir parçası olması gerektiğini bunun da ancak ihtiyaç/beklentilerinin karşılanmasıyla mümkün olacağın belirtmektedir. Kentsel mekân ve çocuk arasındaki ilişkiyi irdeleyen çalışmaların sayısı artmakla birlikte, çocukların kent üzerindeki talep ve beklentilerini ya da bu beklentilerin ne düzeyde karşılandığını net bir şekilde ortaya koyma sorunsalı henüz aşılamamıştır. Çalışmanın üzerinde durduğu temel konu da bu sorunsala dayanmaktadır. Kentsel mekân ve çocuk ilişkisindeki sorunlara yönelik verilerin analiz edilebildiği alanlardan biri de yeni medya haberciliğidir.

Yeni medya haberciliği, yazı, ses, görüntü gibi içeriklerin birlikte kullanabildiği, etkileşim, kitlesizleştirme ve eş zamansız olabilme gibi özellikleriyle geleneksel habercilikten farklılaşan dijital habercilik alanıdır. İnternet gazeteleri, haber siteleri, haber portalları gibi alanları kapsayan yeni medya haberciliğinin bu çalışma açısından en önemli özelliği, toplumda gündelik hayat içerisinde meydana gelen çoğu durumu/olayı yansıtabilmesidir. Çünkü yeni medya, toplumsal yapı içerisinde var olan ilişkileri haberleştirmekte ve ortaya konulan konuyla ilgili sorunları/sorunlara yönelik çözümlemeleri ta- 
nımlamaktadır. Bu doğrultuda çalışma kapsamında ise yeni medya haberlerinde çocuğun kentsel mekânla olan ilişkisi betimlenmektedir. Çalışmanın amacı, yeni medya haberlerindeki "kentsel mekân ve çocuk ilişkisine" yönelik söylemleri irdelemektedir. Elde edilen veriler, hem kentsel mekânların oluşturulması/ tasarımında etkili olan kent yetkililerine önemli noktaları işaret etmesi, hem de konuyla ilgili çalışmak yapmak isteyen araştırmacılara başlangıç noktası oluşturabilecek bilgiler sağlaması adına önem taşımaktadır. Çalışmanın bulguları, kentsel mekân tasarlayıcılarına ve kent yöneticilerine konuyla ilgili önemli ipuçları sağlamakta ve bu konuda çalışma yapmak isteyen araştırmacılara farklı bir bakış açısı sunmaktadır.

Yeni medyada yayınlanan haberlerde kentsel mekân ve çocuk ilişkisine yönelik söylemleri ele alan bu çalışma, beş bölümden oluşmaktadır. Çalışmanın birinci bölümünde kent, kentsel mekân ve çocuk kavramları arasındaki ilişki tanımlanmaya çalışılmıştır. Çalışma, kentsel mekân ve çocuk ilişkisini yeni medya haberciliği üzerinden göstermeyi amaç edindiği için ikinci bölüm, yeni medyada yayınlanan haberlere ayrılmıştır. Çalışmanın ikinci bölümünde, yeni medya haberlerinde çocuğun nasıl temsil edildiği/nelerle ilişkilendirildiği de irdelenmiştir. Üçüncü bölümde, metodoloji bilgileri verilmiş, dördüncü bölümde ise çalışmanın bulguları ve yorumları ortaya konulmuştur. Çalışma, genel değerlendirme ve öneriler kısmını içeren bir sonuç metniyle tamamlanmıştır.

\section{Kent, Kentsel Mekân ve Çocuk İlişkisi}

Kentsel mekân ve çocuk ilişkisi ele alınırken açıklanması gereken ilk kavramlardan biri kenttir. Topal'a göre kent, farklı dönemlerde değişik anlamlara gelen dinamik bir yapıya sahip olduğu için literatürde kavrama yönelik ortak bir tanımlamaya rastlamak çok zordur (2004, s.276). En basit tanımıyla kent, insanların yaşamlarını sürdürdükleri mekân parçasıdır (Tunçer, 2015, s.276). Fiziksel açıdan bu şekilde tanımlanan kenti sosyolojik bakış açısıyla da değerlendirmek gerekmektedir (Özdemir, 2010, s.44). Buna göre, kenti heterojen grupları bünyesinde barındıran, kültürel sermayenin yoğunlaştığı yerler olarak nitelendirmek mümkündür. Kent, sadece yerleşme amaçlı inşayı değil, değişim ve dönüşüm süreci içerisinde yer alan, insanlarla varlık kazanan yaşamı niteleyen toplumsallı̆̆ da ifade etmektedir. Çünkü kentler, tek başına var olan statik birimler değil toplumla ilintili dinamik birimlerdir. Diğer 
bir ifadeyle Keleş'e (2005, s.9) göre kentler, bağlı oldukları ekonomik ve toplumsal figürlerin birer minyatürü, fiziksel olarak yansımasıdır.

Kent kavramının anlamsal ve fiziksel olarak yakın ilişki içerisinde bulunduğu kavramlardan biri de kentsel mekândır. Kentsel mekân, kentin üzerinde kurulan ve kentte yaşayanların kullanımına açık olan alanlardır. Dolayısıyla bu çalışma kapsamında kentsel mekân, kenti niteleyen bir anlatımla ele alınmıştır.

Sosyolojik yönüne yapılan vurguyla dikkat çeken kentsel mekân, içerisinde barındırdığı kullanım alanlarını da benzer şekilde etkilemektedir. Henri Lefebvre'nin "kent hakkı" çözümlemesi, konuyla ilgili önemli tespitler içermektedir. Lefebvre'ye göre adil ve yaşanılası bir kent/kentsel mekân oluşumu, toplumun sınıflı yapısı içerisinde tüm katmanların kent yapısından dengeli bir şekilde faydalanmasıyla mümkündür. Lefebvre, kent hakkı çözümlemesinde, kentsel mekânların kullanım ve biçimlendirme hakkının sermaye sahipleri ve yöneticilerden, kentin asıl sahipleri olan topluma kaydırılması gerektiğini savunmaktadır (2016, s.45-51). Kentleşme hızının artmasıyla birlikte insanların, kamusal alanla olan ilişkisi sınırlandırılmıştır. Toplumlar izole edilmiş özel alanlara doğru itilmeye başlanmıştır. Bu durumdan en çok etkilenen gruplardan biri de çocuklardır. ${ }^{1}$

Hızlı kentleşme olgusuyla birlikte çocukların kent içerisindeki varlığı da değişmeye başlamaktadır. "Modernleşme, batılılaşma ve kapitalizm" gibi kavramlarla dönüşen kentsel mekânlar, biçimsel olarak değişmekte ve çocukları görmezden gelmektedir. Çocuklar farklı yerlere gitmek, sosyalleşmek, çevrelerinde olup bitenlerden haberdar olmak yerine ev içerisinde zaman geçirerek büyümektedir/hayatların sürdürmektedir. ${ }^{2}$ Dolayısıyla evler, kentin geniş gerçekliğinin bir parçası olmak yerine, insanların/çocukların "zamanlarını" geçirdikleri mekânlar haline gelmektedir (Tonucci, 2005, s.184).

Ebeveynler, çocuklarınn "güvenli" olduğunu düşündükleri alanlarda zaman geçirmeleri yönünde bir tutum ve davranış sergilemektedir. Güvenlik

\footnotetext{
${ }^{1}$ TDK'ya göre çocuk "anne karnında ya da bebeklik çağı ile erginlik çağı arasındaki gelişme döneminde bulunan insandır" (sozluk.gov.tr). Birleşmiş Milletler Çocuk Hakları Sözleşmesi'nde ise çocuk; "çocuğa uygulanabilecek olan kanuna göre daha erken yaşta reşit olma durumu hariç, on sekiz yaşına kadar her insan çocuk saylır" şeklindedir (www.unicefturk.org).

${ }^{2}$ Çocuklar, telefon, bilgisayar, tablet gibi araçlar üzerinden Youtube, Instagram, Facebook vb. uygulamaları kullanarak günlerini geçirebilmektedir.
} 
arayışına ek olarak ailelerin konformist yaşam arzusu, ${ }^{3}$ pek çok çalışmada "kentte çocuklar için bir yaşam alanı var mı?" sorusunu gündeme getirmektedir. Bu soruya cevap arayan bazı çalışmalar şunlardır:

Lucio, J. ve I'Anson, kentsel mekân ve çocuk ilişkisini “etkileşimci toplum" kavramıyla analiz etmektedir. Araştırmacılara göre etkileşimci toplum, çocukların yaşadıkları kentlerin bir parçası olabilmesi ve "onların ihtiyaç ve beklentilerini karşılayan mekânların var olabilmesiyle" mümkündür (2015, s.129). Gibson ve arkadaşları da bu ilişkiyi, "çocukluk" üzerinden açılamaktadır. Çocukluk, bir alan olarak tasvir edilirken "oyunda bulunan" anlamına gelen söylemlerle kurulmaktadır (2015, s.322).

Yao ve arkadaşları, çocuğun kentsel mekânda var olma sürecini değerlendirdikleri çalışmasında çocuğun farklı motivasyonlar içerisinde aktif bir rol oynaması gerektiğini belirtmektedir. Çocuğun kentsel mekânla olan ilişkisi eğlenme temelli ise "nasıl oyun oynayacağını", eğitim temelliyse "nasıl bilgileneceğini" kendisi belirlemelidir (2007, s.18). Yani çocuklara kararlarını kendileri verebilmesi ve sonuçlarını üstlenmesi gerektiği öğretilmelidir.

Churchman, belirli yaş aralıkları üzerine yaptığı çalışmasında "çocuk, ebeveyn ve kentsel mekân" kavramları arasındaki ilişkiye odaklanmıştır. Çalışmanın bulgularına göre, çocuklar kentsel mekânları kullanırken ve/veya çocukların kentle olan ilişkisi ebeveynlerine bağımlı olarak gerçekleşmekte$\operatorname{dir}(2003, \mathrm{s.110}-111)$.

Cutumisu ve arkadaşları ise, yaptıkları çalışmada kentsel mekân-çocuk ilişkisini güvenlik ve mekân bilgisi üzerinden ele almıştır. Araştırmacılar, güvenlik çözümlemesini mahalle yapılanmasına dayandırmaktadır. Buna göre mahalledeki yaya ve araç durumu ile çocuğun fiziksel aktiviteleri arasındaki ilişki tespit edilmektedir. Mekân bilgisi ise çocukların yaşadıkları çevre hakkında sahip oldukları bilgilerle yapılı çevrenin daha iyi tespit edilmesini ortaya koymaktadır (2009, s.537).

Bulgularına yer verilen çalışmalar, çocukların kentsel mekânla olan ilişkisini farklı açılardan ortaya koymaktadır. Bu veriler, kentsel mekân ve çocuk arasında yakın bir bağ bulunduğunu göstermektedir. Çalışma kapsamında gerçekleştirilen literatür taramasında "kentsel mekan ve çocuk" ilişkisini konu alan çalışmaların sayıca az olduğu görülmüştür. Özellikle son yıllarda

\footnotetext{
3 Kişisel ihtiyaçlarını giderebilmek adına, çocuklarını alış veriş merkezlerindeki yapay oyun alanlarında oynaması için bırakan ebeveynler, bu konuda bir örnek oluşturabilir.
} 
dünyada ve Türkiye'de çocukların kentsel mekânla olan sınırlı ilişkisi ve bu süreçte çocuklara yeterince yer verilmemesi bu tür çalışmaların artması gerektiğini göstermektedir. Dolayısıyla çalışma kapsamında kentsel mekân ve çocuk arasındaki ilişkinin görünür kılınması adına yeni medyada yayınlanan haberler incelenmektedir. Bu doğrultuda çalışmanın ikinci bölümünde yeni medya haberciliği farklı açılardan ele alınmıştır.

\section{Yeni Medya Haberciliği}

Medya, sürekli teknolojiyle paralel olarak gelişim göstermektedir. Dolay1sıyla teknoloji alanında meydana gelen gelişmeler, iletişim alanında da etkili olmaktadır. Bu bağlamda, teknik gelişmeler geleneksel medyayı da etkilemiş ve "yeni medya" kavramını gündeme getirmiştir (Kürkçü, 2016: s.31). Yeni medya teknolojilerinin ortaya çıkmasına, genellikle eski medyanın ortadan kaybolmasıyla ilgili anlatılar eşlik etmektedir. Yeni medya alanındaki gelişmeler, teknolojinin/dijitalleşmenin gündelik hayatımızda yarattığı dönüşümleri anlamamızı sağlamaktadır (Ballatore ve Natale, 2015, s.1). Bu doğrultuda, yeni medyanın dijitalleşmeyle birlikte internet ortamında yapılan medya alanı/aracı olduğunu söylemek mümkündür. Yeni medya, kısmen geleneksel medyayı içerisinde barındırırken kısmen de yeni sıfatı içerisinde bazı meslek alanlarının oluşmasını sağlamıştır.

Yeni medyayı diğer medya araçlarından farklı kılan özellik, kolaylıkla yeni alanlara eklemlenme özelliğine sahip olmasıdır. Yeni medya, yazılım olarak var olduğundan yalnızca yazılımı değiştirerek ya da yeni bir yazılım oluşturarak özellikler eklenebilmekte hatta içerikler yaratılabilmektedir (Manovich, 2018, s.60-61).

Yeni medya teknolojisiyle İnternet gazeteleri ${ }^{4}$ olarak adlandırılan yeni kitle iletişim aracı, enformasyon akışını internet hızına taşıyarak gazeteciliğin temel ilkelerinin/reflektif pratiğini dönüştürmüş ve yeni medya haberciliğinin oluşmasını sağlamıştır (Van Der Haak vd, 2015, s.73). Günün her saatinde yayınlanabilen haberlerin olduğu bir yapıya bürünen yeni medya haberciliği,

\footnotetext{
4 internet gazeteleri, yeni medya haberciliği içerisinde yer alan mecralardan sadece biridir. Yeni medya haberciliği içerisinde haber siteleri, haber portalları gibi çevrimiçi alanlar da yer almaktadır.
} 
ses, görüntü, grafik ve okur yorumları gibi bileşenleri bir araya getirip (Kalsın, 2016, s.214) düz yazı şeklinde sunulan haberlerin yerini almıştır (Hülür ve Yaşın, 2017, s.10).

Yeni medya haberciliğinde ses, görüntü, metin, grafik, harita, okur yorumları ve daha farklı bileşenleri bir araya getiren dijital hikâye anlatımına dayalı haberler, yalnızca düz yazı şeklinde sunulan haberlerin yerini almıştır. Başka bir deyişle haber, yazı, görüntü ve sesin bir araya geldiği, okur veya izleyicinin herhangi bir ücret ödemeden hızlı ve kolay bir şekilde her yerden erişebildiği, sürekli güncellenen ve farklı araçlarla 24 saat boyunca yayınlanabildiği bir yapıya dönüşmüştür

Bucher ve Schumacher, yeni medya haberciliğinde iki sorunun cevaplanması gerektiğini vurgulamaktadır. Bunlardan birincisi, "haber biçimleri dikkat ve seçicilikle etkileşim içinde midir?" İkinci soruysa "dikkat, istemli midir yoksa istemsiz midir, alıcıların amaçlarına ve doğrularına (kullanıcı-odaklı) mı bağlıdır yoksa bir kimsenin maruz kaldığı medyanın dikkat çekmesine/teşvik etmesine ve ipuçlarına (medya-odaklı) mı bağlıdır? (2016, s.223). Bu iki soruya verilen cevaplar ise şu şekilde kategorize edilmektedir5:

- Spesifik medya uyarıcılarına cevap olarak dikkat örüntülerinin ne ölçüde alıcının amacı tarafından harekete geçirildiğini bulmak için; teste katılan kişiler farklı görev koşulları olan bir Web sitesiyle yüz yüze gelmektedir.

- Dikkat örüntüleri ve medyanın farklı içerikleri arasındaki ilişkiyi soruşturmak için üç farklı gazete türü birlikte (yazılı gazete, çevrimiçi gazete ve dijital editasyon) incelenmelidir.

- Dikkat örüntülerinin, sunum biçimlerine nasıl bağlı oldukları öğrenilmelidir (Bucher ve Schumacher, 2016, s.225).

Gündelik hayatın neredeyse her alanı, yeni medya ve/veya yeni medya haberciliği içerisinde temsil edilebilmektedir. Yeni medya haberlerinde temsil edilen konular, farklı şekillerde değerlendirilerek ele alınan konuya yönelik ekonomi-politik ve sosyo-kültürel ipuçları elde edilebilir.

Son zamanlarda yapılan araştırmalarda medyanın/yeni medyanın çocuğu ön plana alması üzerine bazı çalışmaların olduğu görülmektedir. Örneğin, "çocuk dostu medya düzeni" bunlardan biridir. Akdağ'a göre, çocuk dostu bir medya düzeninin oluşturulması, öncelikli olarak çocuk haklarını ön

\footnotetext{
${ }^{5}$ Okurların haber okuma sürecindeki göz hareketleri, dikkatleri ve seçicilikleri arasında ilişki kurulmaktadır.
} 
planda tutmak ve onları istismar/sömürüden korumak adına önemlidir. Çocuk dostu bir medya düzeni, çocukların da yetişkinler gibi kendi gündemleri olabileceğini kabul eden, çocuk katılımlı bir iletişim ortamının kurulmasına bağlıdır. Çocukları sadece hakları ihlal edildiğinde konu alan habercilik anlayışı yerine çocukların gündemindeki konuları araştıran yeni bir medyaya ihtiyaç duyulmaktadır. Bu bakımdan, çocuklara yönelik kurulan sitelerin sayısı kadar içeriklerinin de çocukları odak noktası yapan bir anlayışla üretilmesi önem taşımaktadır (2016, s.175).

Şirin'e göre çocuk dostu medya düzeni, çoklu medya okuryazarlığı çabasını bir sonucudur. Çocukları medyanın olumsuz etkilerinden korumak amacıyla yapılacak düzenlemelerden önce, medyanın içeriğine çocuğun öncelikli yüksek yararına dayalı bir anlayışın yansıtılması gerekir. Burada sorulması gereken ana soru şudur: Çocuk bakışına ve çocuk haklarına dayalı çocuk dostu iletişim ortamının hazırlanması için hangi düzenlemeler yapılmalıdır? Ulusal ve uluslararası düzenlemeler, medyaya erişimi sınırlandırmamalı aksine zararlı içerikten korumalıdır. Bu bağlamda çocuk ve medya ilişkisini etik ve hukuki olduğu kadar pedagojik boyutuyla da değerlendirmek gerekmektedir (2018, s.9-10). Yeni medyanın kazanımlarını ve kayıplarını değerlendiren bir medya pedagojisi anlayışı içerisinde, çocuk bireylerle yeni medya teknolojileri arasındaki ilişkinin daha kontrollü olması için ders içerikleri dikkatle hazırlanmalıdır (Kılınç ve Kılınç, 2018, s.16, 18). Yani çocuk dostu medya düzeni, çocukları merkeze alan ve onların fikir ve düşüncelerini dikkate alan bir yapıda olmalıdır.

Konu bütünlüğünü güçlendirmesi adına yeni medya haberciliğinde çocuk olgusunu irdeleyen bazı çalışmaların bulguları şu şekilde özetlemek mümkündür:

Arslan (2019, s.115-116), “Eleştirel Medya Okuryazarlığ1 Kapsamında Çocuğa ve Kadına Yönelik Olarak Önerilen Özel Haber Dili” adlı çalışmasında çocukları, yeni medya içerisinde yer alan sosyal medyayla olan ilişkileri çerçevesinde incelemiştir. Çalışmada, gittikçe artan kadın ve çocuk cinayetleri haberlerinin medyada yer alması, toplumsal farkındalığı artırmak adına önemli görülmektedir.

Atalay (2019, s.179) da Arslan gibi yeni medya teknolojileri içerisinde çocuk kavramını incelemiştir. Atalay'a göre, yeni medya teknolojilerinin toplumlarla etkileşimi arttıkça dijital kapitalizm, her şeyi metalaştırma imkânı elde etmektedir. Kapitalizmin dijital dünyadaki yansımasına çocuklar hem 
tüketici hem de meta olarak dâhil edilmiştir. YouTube ve benzeri sosyal medya mecraları için Türkiye'de yasal kullanım yaşı on üçtür fakat yaş ortalaması bu sınırın çok altına inmiş durumdadır. Çocuklar, sosyal medyayı kullanım sürecinde psikolojik ve fiziksel gelişimlerini olumsuz etkileyecek bir sürecin içerisine girebilmektedir.

Bulck ve ark. yaptıkları çalışmalarında, yeni medya ve çocuk ilişkisi üzerine yapılan araştırmaların daha sağlıklı olması için bazı çözümlemelerde bulunmaktadır. Yazarlara göre, medya ve çocuk üzerine yapılan çalışmalarda, ebeveynlerin üzerine odaklanılması ve ebeveynlerden elde edilen sonuçlarla çocuklar adına bir söylem inşa edilmesi sakıncalıdır. Çalışmada, medya alanına yönelik yapılan araştırmalarda, çocukların kendilerinin özne konumunda yer alması gerektiğini vurgulamaktadır (2016: s.35).

Yeni medya haberlerinde çocuk olgusunu irdeleyen çalışmaların odak noktası, çocuk dostu bir medya düzenine yapılan vurgudur. Bu düzenin oluşturulabilmesi adına, medya okuryazarlığına önem verilmesi, ebeveynlerin ve çocukların ayrı ayrı bilinçlendirilmesi gerekmektedir. Böylece çocukların, kentsel mekân içerisindeki talepleri, istek ve şikâyetleri doğrudan öğrenilebilecektir.

\section{Yöntem}

Bu çalışmada, haber metinlerinde "kentsel mekân ve çocuk ilişkisi" irdelenerek, konuyla ilgili anlamsal/metinsel ve sosyo-politik ilişkilere yer verildiğinden "eleştirel söylem analizi" yönteminin kullanılması uygun görülmüştür.

Eleştirel söylem analizi, sözlü ve yazınsal metinleri inceleyerek metin içerisinde yer alan unsurlardan hareketle daha derin anlamları ortaya çıkaran bir yöntemdir. Eleştirel söylem analizi, bir yöntem olmakla birlikte bir çalışma alanını da kapsamaktadır. Eleştirel söylem analizi, 1970'lerde eleştirel dil bilim çalışmalarına paralel olarak ortaya çıkmıştır (Fairclough ve Graham, 2003, s.189).

Eleştirel söylem analizi, “İnsanların bilgilerini, değerlerini, görüşlerini, inançlarını, sosyal ilişkilerini, değerlendirmelerini, psikolojik ve sosyal altyapılarını, kişiliklerini, kimliklerini, niyetlerini, yargılarını ve algılamalarını yansıtan söylemi inceleyerek bilimsel araştırmaların kullanımına sunan söylem çözümlemesi gün geçtikçe daha fazla araştırmada ve daha fazla bilimsel 
alanda kullanılan bir yöntemdir." (Gür, 2013, s.189). Dilin sosyal yapıdaki etkinliğini belirleyip betimlemekten çok, bunu nasıl ve niçin yaptığını inceleyen eleştirel söylem analizinde ön plana çkan isimler, Teun Van Dijk, Norman Fairclough ve Ruth Wodak olarak siralanabilir.

Van Dijk'ın eleştirel söylem analizinde ortaya koyduğu temel kavramlardan ikisi makro ve mikro düzeydir. Makro düzeyde incelenen ses, görsel veya yazınsal içerikli unsurlarda inşa edilen tahakküm yapıları ortaya konulurken mikro düzeyde ise dilin kullanımı, tanımladığı söylem üzerinde durulmaktadir.

Van Dijk'ın haber çözümlemesinde ortaya koyduğu model, "makro ve mikro" olmak üzere iki bölümden oluşmaktadır. Makro yapı bölümü iki başlık içerisinde incelenmektedir: "Tematik çözümleme ve şematik çözümleme." Makro çözümlemede haber metinleri, başlık ve girişte yer alan ifadeler kullanılmaktadır. Burada yapılan çözümlemeyle metin özetlenmekte ve haberin teması, haber kaynakları, ardalan ve bağlam bilgisi öğrenilebilmektedir (Özer, 2011, s.83). Mikro yapıda ise "sentaktik çözümleme, kelimeler arası bölgesel uyum, sözcük seçimleri ve retorik" çözümlemeleri yapılır. Haberin mikro analizi, cümle yapılarından, sözcük seçimlerine ve yan anlamlarına kadar haber metninin derinlemesine analizini içermektedir (Akca, 2009, s.101).

Eleştirel söylem analizlerini dil bilimsel analiz (gramer analizi )ve metinler arası analiz (dil ve güç, iktidar ilişkileri vb.) olmak üzere iki noktaya ayıran Fairclough, eleştirel söylem çözümlemesinde üç noktayı ön plana çıkarmaktadır. Bunlar: "Metin, söylem uygulaması (üretim ve tüketim süreçleri), ve sosyokültürel uygulamalardır." Bu noktalar, Van Dijk'ın ideolojik çözümlemesindeki, söylem, sosyo-bilişim ve sosyal çözümleme (sosyal yapıların çözümlenmesi) boyutlarıyla benzerlik göstermektedir. Van Dijk söylem ve sosyal boyut arasındaki ilişkinin zihinsel modellerce gerçekleştirildiğini savunurken Fairclough ise bu görevin söylem uygulamaları (metin üretimi ve tüketimi) tarafından yerine getirildiğini ileri sürmektedir (Mora, 2008, s.21).

Wodak ise eleştirel söylem analizinde "ideoloji ve güç ilişkilerini" ön plana çıkarmaktadır. Wodak'a göre, dil ve söylem arasındaki ilişki incelenerek toplum/yapı içerisindeki eşitsizlikler, görmezden gelinen noktalar ve tahakküm ilişkileri ortaya konulabilir. Belirli kıstaslarla veya belirli tematik çerçevelerle yapılan analizlerde birden çok alana yönelik verilere ulaşılabilir. Diğer bir ifadeyle Wodak'a (2001, s.3, 11) göre eleştirel söylem analizi, dilbilim, psikoloji ve sosyal bilimlerle yakından ilgilidir. Bununla birlikte pratiğe 
ve/veya teoriye dair olan temaların analizinde "retorik, üslup, grammer vb." dilsel unsurlar oldukça önemlidir.

Eleştirel söylem çözümlemesinin yukarıda ana hatlarıyla açıklanan üç uygulamasından da anlaşılacağı gibi bu yöntemde araştırmacılar kendi bakış açlarına, araştırdıkları konunun özelliklerine göre ve eldeki verilerin niteliğine göre değişik uygulamalar ortaya koymuşlardır. Buna rağmen çalışmaların ana kısmında dilsel ürünün özellikleri; psikolojik, sosyolojik, tarihsel ve kültürel altyapı olarak tanımlanabilecek bağlam ve söylem-üretici-algılayan ilişkisinin incelenmesi yer almaktadır (Gür, 2013, s.199).

\section{Evren ve Örneklem}

Bu çalışmanın evreni, yeni medya haberciliği yapan internet gazeteleri ve haber siteleridir. Çalışmanın örneklemi ise internet sitelerinin tıklanma ve internet sitelerinde geçirilen zaman dilimini detaylı bir şekilde ortaya koyan Alexa.com adlı sitenin verilerine göre belirlenmiştir. Alexa.com verilerine göre, ${ }^{6} 1$ Haziran- 1 Temmuz 2019 tarihleri arasında yeni medya haberciliği yapan siteler içerisinde yer alan ilk beş site analiz edilmiştir. Bu gazete/haber siteleri, "ensonhaber.com, hürriyet.com.tr, aksam.com.tr, mynet.com ve sözcü.com.tr" adlı gazete/haber siteleridir. ${ }^{7}$ Dolayısıyla adı geçen sitelerde yayınlanan haber metinlerinden elde edilen veriler, yeni medya haberciliğine/haberlerine ilişkin veriler olarak genel bir çerçevede değerlendirilmiştir.

\section{Araştırma Sorulan ve Varsayımı}

Araştırmanın varsayımı, "çocuklar gündelik hayatta fiziksel ve ruhsal tehditlerle karşılaştıkları için kent içerisindeki kamusal alanları kısıtlı kullanmaktadır" şeklindedir. Çalışma kapsamında, yeni medyada yayınlanan haberlerde "kentsel mekân ve çocuk" ilişkisini ortaya koymak adına cevaplanmaya çalış1lan 3 araştırma sorusu belirlenmiştir:

- Yeni medyada yayınlanan haberlerde "kentsel mekân ve çocuk" ilişkisi, hangi söylemlerle/kategorilere inşa edilmektedir?

\footnotetext{
${ }^{6}$ Alexa.com verileri, kullanıcıların/okurların Türkiye'de ziyaret ettiği sitelerin tıklanma ve ziyaret esnasında ayırdıkları zaman dilimini detaylı olarak gösteren güvenilir bir site olması sebebiyle seçilmiştir.

7 Alexa verilerine göre, ensonhaber.com 6.sırada, hürriyet.com.tr 14.sırada, aksam.com.tr 16.sırada, sözcü.com.tr 20.sırada ve mynet.com 22. sırada yer almaktadır.
} 
- Yeni medya yayınlanan haberlerde "kentsel mekân ve çocuk" ilişkisi kurulurken ortaya konulan sorunlar nelerdir?

- Yeni medya yayınlanan haberlerde "kentsel mekân ve çocuk" ilişkisi kurulurken önerilen çözümler nelerdir?

\section{Kapsam ve Stnırlılıklar}

Araştırmanın zamansal kapsamı 1 Haziran- 1 Temmuz 2019 olarak belirlenmiştir. Evren ve örneklem kısmında belirtilen haber siteleri dışında kalan internet ve haber sitelerinde yer alan veriler, araştırmanın sınırlı tarafını oluşturmaktadır. Araştırma kapsamında yer alan mynet.com adlı haber sitesinde, araştırma kapsamında belirlenen süre içerisinde doğrudan "kentsel mekân ve çocuk" ilişkisini içeren bir haber metni yayınlanmadığı için bu sitenin haberleri, analiz edilememiştir. Ayrıca araştırma kapsamında yer verilen haber sitelerinden biri olan "aksam.com.tr" adlı gazetenin arşivleme sisteminde konuyla ilgili verilerin sadece 1-17 Haziran arası yer aldığı görülmüştür. Dolayısıyla araştırma kapsamında analiz edilen diğer 4 gazete/haber sitesi 1 aylık süre zarfında incelenirken aksam.com.tr'de yayınlanan haberler, 17 günlük süre içerisinde incelenebilmiştir.

\section{Verilerin Elde Edilmesi ve Kullanilan Model}

Araştırmada analiz edilen haber metinlerine yeni medya haberciliğinin temel özelliklerinden biri olan "depolama ve arşivleme" kullanılarak ulaşılmıştır. Diğer bir ifadeyle analiz edilen haber siteleri ve internet gazetelerinin arama butonuna "çocuk" anahtar kavramı yazılarak, çocukla ilgili haberlere ulaşılmıştır. Kapsam ve Sınırlılıklar kısmında belirtilen zaman dilimi içerisinde analiz edilmek üzere belirlenen habercilik siteleri içerisinde "kentsel mekân ve çocuk" ilişkisiyle ilgili olan haber metinleri belirlenmiştir. Çalışmanın konusu ve amacına uygun olarak amaçsal örnekleme tekniğiyle "kentsel mekân ve çocuk" ilişkisini en iyi yansıttığı düşünülen bu haber metinleri, eleştirel söylem analizi yöntemiyle analiz edilmiştir. Haber metinleri, ön bir inceleme sonucu belirlenen şu kategorilere göre çözümlenmiştir:

- Çocuk ve Oyun Alanları

- Çocuk ve Sosyal Aktivite Alanları

- Çocuk ve Eğitim Alanları 


\section{Yeni Medya Haberlerinde Çocukların Kentsel Mekân İçerisindeki Konumuna Yönelik Bulgular ve Yorumlar}

Bu bölümde araştırmacının ön inceleme sonucu belirlediği kategorilere ait bulgulara ve yorumlara yer verilmiştir. Elde edilen bulgular ve yorumlarla yeni medyanın gündelik hayatta çocukların kentsel mekân içerisindeki talepleri/ çocuklara uygun olması gereken bazı kentsel mekânlar farklı açılardan ortaya konulmaya çalışılmıştır.

\section{Çocuk ve Oyun Alanları}

Bu kategori içerisinde, çocukların kentsel mekânlarda vakit geçirdiği/ vakit geçirmesi gereken temel kamusal mekânlardan biri olan oyun alanları ele alınmıştır. Burada çocukların park, sokak ve yeşil alan gibi oyun alanlarında nasıl temsil edildikleri haber metinleri üzerine analiz edilmiştir. Oyun alanları kategorisi kapsamında ensonhaber.com, sözcü.com.tr ve hürriyet.com.tr adlı sitelerde yayınlanan haber metinleri analiz edilmiştir. Bu analizlerin sonuçları göre çocukların, oyun alanlarında farklı tehlikelerle karşı karşıya kaldıklarını göstermektedir.

Ensonhaber.com'da, "Çocuk parkı girişine pitbull zincirlediler" başlıklı ${ }^{8}$ (27.06.2019) ve "Bursa' da çocuk parkındaki yılanlar panik yarattı" başlıklı haber metinlerinde (29.06.2019) çocukların hem doğal hem de önlem alınmadığı için bir takım tehlikelerle karşılaştı̆̆ görülmektedir. Pitbull içerikli haber metninde yer alan ifadeler, ${ }^{9}$ çocukların köpeklerden korktukları için temel oyun/zaman geçirme alanlarına erişemediklerini göstermektedir. Yılan gibi ölümcül tehlikeler saçan bir hayvanın çocukların oyun alanlarına erişebilmesi ise ilgili birimlerin bu konuda bir tedbirsizliğin göstergesidir. Sözcü.com.tr'de (20.06.2019) “Çocuk parkında elektrik çarpan çocuk hayatını kaybetti" başlıklı haber metninde, yine ihmalden kaynaklı bir tehdidin varlığ 1

\footnotetext{
8 Pitbull, 5199 sayılı Hayvanları Koruma Kanunu'na göre, Türkiye'de üretilmesi, sahiplendirilmesi dahi yasak olan bir köpek türüdür.

9 "Muhtar Yesirci, Gördüğünüz alan Cedidiye Mahallesi Fettah Bey Parkı. Saat 01.00 civarında kimliğini tespit edemediğimiz şahıslar, köpekleri parka bırakmışlar. Pitbull cinsi köpekler. Çocuklar parka giremediler korkudan"
} 
görülmektedir. Haber metninde, 12 yaşındaki çocuğun parkta oyun oynarken elektrik çarpması sonucu hayatını kaybettiği anlatılmaktadır. ${ }^{10}$ Haberde, bu tehlikenin giderilmesi adına yerel anlamdaki bazı birimlerin sürekli bilgilendirildiği belirtilmekte ve sorumluların cezalandırılması talep edilmektedir. ${ }^{11}$ İlgili kurum ve kuruluşların bu süreci daha dikkatle incelemesi ve çocukların kentsel mekân içerisinde en çok kullandığı alanlardan biri olan parkların güvenliğine daha çok önem vermesi gerekmektedir. Aksi takdirde çocukların kentsel mekân içerisindeki geçirdikleri zamanın kaliteli ve verimli olmasını sağlamak mümkün görünmemektedir.

"Ataşehir'de parkta çekirdek poşetinde uyuşturucu sattı" başlıklı haber metni, (30.06.219) çocuklar için, doğal oyun alanlarında karşılaştıkları farklı bir tehlikenin altını çizmektedir. Haber içeriğinde yer alan ifadeler ${ }^{12}$, öncelikle çocuklara ayrılan bir kentsel mekânın, güvenlik dışı alanlara dönüştürülmeye çalışıldığını göstermektedir. Parkta çekirdek poşetinde uyuşturucu satılması, çocukları kötü alışkanlıklara itecek bu davranışların kent yöneticileri ve emniyet mensubu gibi kişi/kuruluşların kontrolü altında olmadığını göstermektedir. Özenti ve merak duygularının gelişme sürecinde olan çocuklar için bu durum oldukça tehlikeli olabilir ve kalıc hasarlar bırakan sonuçların doğmasına yol açabilir.

Oyun alanları içerisinde sayılan bir diğer kamusal mekân sokaklardır. Kentlerde nüfus yoğunluğunun artmasıyla birlikte araç sayısının artması çok katlı binaların çoğalması sonucu sokaklar çocukların kullanım alanları dışına kaymaya başlamıştır. Hürriyet.com.tr adlı internet gazetesinde "Apartman önünde oyun oynayan çocuğa ve ailesine dayak" başlıkl113 (26.06.2019) ve "Sokakta çocukların oyun oynamasına sinirlenip dehşet saçtı" başlıkl1 ${ }^{14}$

\footnotetext{
10 “Murat-Birten Bağlan çiftinin iki çocuğundan küçük olan 12 yaşındaki Onur Bağlan arkadaşlarıyla birlikte evlerinin önünde bulunan Hüseyin Aksoy Parkı'nda oynamak için dışarı çıktı. İddiaya göre arkadaşlarıyla birlikte oyun oynayan küçük çocuk, parkın içerisinde bulunan aydınlatma direğinin yanından geçerken elektrik akımına kapıldı."

11 "Ben sürekli park bahçeleri, beyaz masayı arıyorum. Dün köpek orada elektriğe tutuldu. Burada kimin sorumluluğu varsa cezasını çeksin. Bugün Onur gitti yarın başka Onurlar gitmesin."

12 “Polis ekipleri, İçerenköy Mahallesi Huzur Hoca Caddesi'nde bulunan parka uyuşturucu satmak için geldiği belirlenen Türkmenistan uyruklu 41 yaşındaki Gülran K.'yi yakaladı"

13 "Özen Ailesi'nin 5 yaşındaki çocukları C.D.Ö., arkadaşlarıyla oyun oynamak için sokağa çıktı. Aynı sokaktaki bir apartmanın kapısının önünde oynarken rahatsız olan kadın, dışarıya çıkıp çocuğu dövdü."

14 "Denizli'de çocukların sokakta oynamalarına ve kadınların kapı önünde oturmasına kızan şahıs ile çocukların aileleri arasında meydan muhaberesi gibi kavga yaşandı".
} 
(22.06.2019) haberler kamusal alanın bir parçası olan sokağın, çocukların şiddete uğradığı bir alana dönüştüğünü göstermektedir. 26.06.2019 tarihli haber metninde 5 yaşındaki bir çocuğun sokakta top oynamasından rahatsız olan birinin önce çocuğu sonra da ebeveynlerini darp ettiği belirtilmektedir. Geçmişte, çocuklar günlerinin önemli bir kısmını sokakta geçirirlerdi. Kapı önünde oturan komşularsa onları dışarıdan gelecek tehlikelere karşı korurdu. Son dönemlerde kamusal alanların kullanım sıklığının azalması bu durumu tersine çevirmekte ve çocuklar, günün önemli kısmını evlerinde geçirmektedir. Çocuklar, evlerinin bulunduğu sokakta dahi sınırlı zaman harcamaktadır. Geçmişte bir güvenlik unsuru olan komşular ise çocuklar için bizzat tehlike unsuru olabilmektedir. Özellikle çocuklar için önemli sayılabilecek kentsel mekânlardan biri olan sokak, çocukların çocukluğunu yaşayabilecekleri bir alan olmaktan uzaklaşmaktadır. Çocukların vakit geçirebileceği kamusal alanlar, bu tür tehlikelerden arındırılmadığı için ebeveynler onlar adına endişe duymakta ve çocukları gündelik hayat içerisinde büyüyebilecekleri doğal kentsel mekânlardan ziyade alışveriş merkezleri gibi yapay alanlara yönlendirmektedir. Bu süreç, çocukların her şeyi önceden belirlenmiş bir programlamayla büyümelerine ve gündelik hayat içerisinde karşılaşabilecekleri zorluklarda/ilişkilerde güçsüz kalmalarına neden olabilmektedir. Diğer bir ifadeyle geçmişte, "uçurtma uçurulan, misket oynanan, ip atlanan, taş oyunları-top oyunları oynanan" başlıca alanlardan biri olan sokak ile çocukların artık sınırlı etkileşimi söz konusu olmaktadır. Çocukların psikomotor gelişimlerinin sağlıklı olabilmesi ve fiziksel ve ruhsal oluşumlarının doğalarına uygun bir şekilde gerçekleşebilmesi açısından kent yöneticilerinin, çocukların sokaklarda güvenli ve verimli bir şekilde zaman geçirmelerini sağlamak adına gereken önlemleri alması ve uygulamalarını bu yönde geliştirmesi gerekmektedir.

\section{Çocuk ve Sosyal Aktiviteler}

Bu kategori altında kentsel mekân içerisinde çocuklar için olması gereken sosyal aktivite mekânları irdelenmiştir. Yüzme, spor, boş zaman değerlendirmesi gibi sosyal aktivitelerin olması gereken alanlardan ziyade tehlikeli olabilecek mekânlarda gerçekleşmesi ve karşılaşılan sonuçları üzerinde durulmuştur. "Çocuklar Gezi Parkı'ndaki havuzda serinledi" başlıklı (25.06.2019) ve "Batmanlı çocuklar süs havuzlarında serinledi" başlıklı (16.06.2019) haber 
metinlerinde çocukların sıcaklara dayanamayarak süs havuzlarına girdikleri ifade edilmektedir. Çocuklar serinleme mekânları olarak süs havuzları, dereler ve su birikintileri gibi alanları kullandıklarında "boğulma, elektrik akımına kapılma, su yoluyla bulaşan hastalıklara yakalanma ve hayatlarını kaybetme" gibi tehlikelerle karşılaşmaktadır. 14.06.2019 tarihli haberde de Şırnak'ta, yaşları 9-13 arasında değişen bir grup çocuğun yaşadıkları ilçeye yakın olan bir köye giderek burada yüzdükleri belirtilmektedir. "Şırnaklı çocuklar soluğu derede alıyor" başlıklı haberde farklı bir tehlike daha ortaya çıkmaktadır. Tehlike farklılaşmakta fakat çocukların talepleri aynı olmaktadır. "Suriyeli çocuk su birikintisinde boğuldu" ana başlıklı (06.06.2019) haberde, 16 yaşındaki bir çocuğun Adana' da serinlemek için girdiği suda hayatın kaybettiği belirtilmekte ve haber durumun tehlikesinin somut örneğini oluşturmaktadır. 25.06.2019 tarihli haber metninin inşa edildiği söylem oldukça sakıncalı ve çocukların hangi tehlikelerle karşı karşıya kaldıklarını görmezden gelici ve sakıncalıdır. ${ }^{15}$ 16.06.2019 tarihli haberde ise dikkat çeken ilk nokta tehlikenin farkındalığıdır. ${ }^{16}$ Özellikle yaz aylarında serinlemek adına kentsel mekân içerisinde uygun yer bulamayan çocuklar, kentin farklı yerlerinde yer alan süs havuzlarına girerek serinlemeye çalışmaktadır. Havuzun kirliliği ve elektrik tehlikesine karşı çocuklar sadece serinlemek adına bilinçli/bilinçsiz bir şekilde hayatlarını riske atmaktadır. Başka çareleri olmadığını belirten çocukların süs havuzlarındaki elektrik akımlarına kapılma ve boğulma gibi tehlikeleri hakkında bilinçli olabilecek bir yaş grubunda olmadıkları gözden kaçırılmamalıdır. Çocukların, kent içerisinde serinlemek adına yetkililerden kaliteli zaman geçirebilmeleri için havuz talep ettikleri de belirtilmiştir. ${ }^{17}$ Ana başlık ve alt başlıktaki bilgiler, ara başlıklarla ${ }^{18}$ birleştiğinde havuz/serinlemek için kullanılan tehlikeli mekânların sırf daha erişilebilir olduğundan çocuklar için öncelikli kullanıldığı görülmektedir. Bu yüzden bahsi geçen tehlikelere karşı çocukları korumak adına öncelikle kentsel

\footnotetext{
15 "Sıcak havadan bunalan çocuklar, Taksim Gezi Parkı'ndaki süs havuzuna girerek sıcak havanın tadını çıkardı." "Park içerisindeki havuzda yüzen ve oyunlar oynayan çocuklar, çevredekilerin ilgi odağı oldu." 16 "Haberde yer alan ifade şu şekildedir: "Gercüş'te yaz aylarında artan sıcaklıklara dayanamayan çocuklar, tehlikeye aldırış etmeden Bağlarbaşı Mahallesi Kazım Koyuncu Bulvarı'nda bulunan süs havuzuna girdi."

17 "Çocuklar, havaların sıcak olmasından dolayı süs havuzlarına girdiklerini söylediler. Çocuklar, kentte havuz olmadığını ve serinlemek için başka bir çarelerinin olmadığını belirterek, yetkililerden ilçeye havuz yapılmasını istediler."

18 "Serinlemek için girdi", "Vatandaşlar çıkardı", "Bir Suriyeli daha denizde kayboldu", "Boğulma sayısı şimdiden 5'e yükseldi."
} 
mekân içerisinde kullanışlı, tehlikesiz ve ulaşılabilirliği kolay serinleme alanlarına yer verilmelidir. Ayrıca hem çocukların hem de ebeveynlerin bu tehlikeler karşısında bilinçlendirilmesi gerekmektedir. Diğer bir ifadeyle sadece kent yönetiminde değil bu tür tehlikelerin/zararların neler olabileceğini öngören vatandaşların da bu noktada çocukların talep ve beklentilerini kent yöneticilerine iletmeleri gerekmektedir.

Sosyal aktivite kategorisinde ayrica spor ve piknik temalı alanlar da ele alınmıştır. Ensonhaber.com adlı haber sitesinde 22.06.2019 tarihinde "Boş araziye halı seren çocukların futbol aşkı" başlığıyla yayınlanan haber metninde, çocukların kendilerine bir sosyal aktivite zemini hazırlama süreçleri dile getirilmektedir. Çocuklar, taşlarla dolu olan bir alanı temizleyerek evlerinden getirdikleri halı ve kilimleri bu alana sermiştir. Bir halı sahaya benzetmeye çalıştıkları alanda futbol oynamışlardır. Haber metni, çocukların kent içerisinde ilgileri doğrultusunda bir sosyal aktivite gerçekleştirmek ve kendilerine ait bir kentsel mekân/alan inşa etmek adına yaptıkları bir davranışı ortaya koymaktadır. Bu durum, çocukların sosyal aktivitelerini daha konforlu gerçekleştirebilecekleri alanlara ihtiyaç duyduklarını göstermektedir. Yine aynı sitede yayınlanan "Yürüyen merdivende oynayan çocuklar" (07.06.2019) başlıklı haber metni de ${ }^{19}$ çocukların kentsel alan içerisinde oyun oynayacak alanlar bulamadıkları için kendileri adına tehlike oluşturabilecek noktaları kestiremeden oyun oynadıklarını göstermektedir. Haberler farklı olmakla birlikte sorun tektir. Çocuklara kent içerisinde ayrılan mekânlar yetersizdir. Bu yüzden de çocuklar doğal oyun alanlarında oynamak yerine karşılaşabilecekleri tehlikeleri göz önüne almadan risk taşıyan alanlarda zaman geçirmektedir. Gerekli önlemler alınmadığı için çocukların, ebeveynleriyle birlikte gerçekleştirdikleri sosyal aktivitelerde dahi zarara uğrayabildiğini/hayatlarını kaybedebildiğini gösteren söylemler karşımıza çımaktadır.

19 "Taksim Metro istasyonu'nun girişindeki yürüyen merdivenleri adeta kaydırak gibi kullanan çocukların tehlikeli oyunu görenleri hayrete düşürdü." 


\section{Çocuk ve Eğitim Mekânlarn}

Çocuklar için eğitim hakkı en temel hak kapsamında ele alınmaktadır. ${ }^{20}$ Dil, din, ırk gibi hiçbir ayrım gözetmeden kullandırılması öngörülen eğitim hakkının ulaşılabilir olması da gerekmektedir. Hem temel eğitim hem dini eğitim mekânlarında çocukların karşılaştıkları sorunlar bu kategori içinde analiz edilmeye çalışılmıştır.

Ensonhaber.com'da (12.06.2019) tarihinde “Kreşte 2 yaşındaki çocuk darbedildi" başlığıyla yayınlanan haber metni, çocuğun eğitim hayatının daha ilk aşamasında şiddetle karşı karşıya kaldığını göstermektedir. Haberin alt başlı̆̆ında yer alan ifadeler ${ }^{21}$, bir eğitim mekânında yer almaması gereken ve cezai yaptırımları dahi bulunan şiddetle karşı karşıya kalabildiklerini göstermektedir. Olayın bir kreşte meydana gelmesi, konunun vahametini daha da artırmaktadır. Çocuğun kendini hiçbir şekilde savunamadığı bir yaşta darp edilmesi, onun tüm eğitim kurumuna olan güvenini yıkabilir ve çocuk eğitime erişim hakkından yoksun bırakılabilir.

"Camide üzerine ayakkabı dolabı devrilen çocuk öldü" başlıklı ensonhaber.com'a ait haberde ${ }^{22}$ (20.06.2019) ve “7 yaşındaki çocuk Kur'an kursunda feci şekilde öldü!'” başlıklı sözcü gazetesi haberinde çocukların dini eğitim aldıkları ibadethane mekanlarında bazı tehlikelerle karşılaşabildiğini göstermektedir. Toplumun temel dinamiklerinden biri olan dini bilgileri edinmek üzere gittikleri mekânlarda risk taşıyan unsurların bulunması çocuklar için bu alanların tehlikeli olduğunu göstermektedir. Çocukların eğitimlerinin aksamaması için eğitim alanlarına güven duyabilmeleri sağlanmalı, eğitsel mekânların içerisindeki fiziksel unsurlardan (mekân içerisinde bulunan dolap vb. eşyaların duvarlara iyi monte edilmesi gibi) kaynaklı zarar görmemelerini sağlayacak önlemler alınmalıdır.

\footnotetext{
${ }^{20}$ Birleşmiş Milletler Çocuk Hakları Sözleşmesi 28. Madde https://www.unicefturk.org/public/uploads/files/UNICEF CocukHaklarinaDairSozlesme.pdf Erişim Tarihi: 20.07.2019).

21 "Antalya'da yaşayan aş̧ı H.Y., özel bir kreşe bıraktığı 2 yaşındaki erkek çocuğunun şiddet gördüğünü ileri sürerek savciliğa suç duyurusunda bulundu."

22 "Kocaeli'de Kur'an kursuna kayıt yaptırmak için babasıyla camiye giden 7 yaşındaki çocuk, üzerine ayakkabı dolabı devrilmesi sonucu yaşamını yitirdi."
} 


\section{Sonuç ve Tartışma}

Yeni medyada yayınlanan haberlerde yer alan kentsel mekânlardaki çocukların temsilini konu edinen bu çalışma, medyanın "gündelik hayat içerisindeki sorunları tanımlama" özelliği üzerine inşa edilmiştir. Çocukların gündelik kullanım alanlarını verimli kullanamadıkları gerçeği yeni medya haberlerindeki farklı söylemlerle gösterilmeye çalışılmıştır. Kentsel mekân ve çocuk ilişkisinin yeni medyada yayınlanan haberlerde "oyun, sosyal aktivite ve eğitim alanları" gibi kategorilerle inşa edildiği ve bu kategorilere bağlı söylemlerle kurulduğu görülmüştür.

Çalışma bulguları, çocukların risk taşıyan bölgelerde zaman geçirdiklerinde bu konuda gerekli önlemlerin alınmadığı için bedelini canlarıyla bile ödediklerini göstermektedir. Kentsel mekân çocuk ilişkisinin yeni medya haberlerindeki örnekleri, "şiddet, uyuşturucu, yetersizlik ve güvensizlik" söylemleriyle yayınlanmıştır. Çocuklar, sokak gibi kentsel mekânlarda ve eğitim gördükleri kreşte şiddet görmekte, park gibi kentsel mekânlarda uyuşturucuyla tanışmakta, serinlemek için süs havuzlarını ve su birikintilerini kullanmakta ve sosyal aktivitelerini gerçekleştirmek istedikleri piknik alanlarında hayatlarını kaybetmektedir. Yeni medya haberleri söylemlerinde, çocukların kentsel mekânlardaki en büyük iki sorununun, "güvensizlik ve yetersizlik" olduğu söylenebilir. Çocukların, yaşadıkları kentlerde ihtiyaç ve motivasyonlarını kolay erişilebilir fakat hiçbir güvenlik önleminin alınmadığ mekânlarda gidermeye çalıştıkları görülmüştür. Çocuklarla ilgili tüm kamusal alanlarda onların fiziksel ve ruhsal güvenliklerini koruma altına almakla yükümlü olan yetkililerin bu konuda bir ihmalleri olduğunu söylemek yanlış olmayacaktır.

Çocuklar, kendilerine en yakın olan bu mekânların ne gibi riskler taşıdığını hesaplamadan kullanmaktadır. Örneğin, haber örneklerinde görüldüğü üzere çocuklar, serinleme ihtiyaçlarını gidermek adına kent içerindeki süs havuzlarını veya su birikintisi içeren mekânları kullanmaktadır. Bu ihtiyaçların çocuklar tarafından giderilmeye çalışılması, sudan bulaşan hastalıklardan/ elektrik çarpmasından hayatlarını kaybetmelerine kadar her türlü tehlikeyi beraberinde getirmektedir. Yetersizlik sorunsalında dikkat çeken bir başka örnekte futbol oynamak için ihtiyaç duydukları halı saha olmadığından evden getirdikleri halıları sokağa sererek kendilerine top oynama alanı inşa eden çocukları konu edinen haber metnidir. Çocukların kentsel mekânların 
yetersizliği yanında bir diğer sorun ise güvensizliktir. Bu güvensizlik, çocukların kentsel mekân içerisinde karşılaştıkları tehlikeler sonucu oluşan bir duygu sürecidir. Çocuklar temel oyun alanlarından biri olan/olması gereken parkta ve sokakta, "şiddet ve kötü alışkanlıklar" gibi tehlikelere maruz kaldıklarında bu mekânları özgürce kullanmakta sıkıntı yaşamaktadır.

Çocukların kentsel mekânlarda yaşadıkları sorunların çözümlerine yönelik ipuçlarını da yeni medya haberleri söylemlerinde bulmak mümkündür. Çocuklar ve ebeveynleri, yukarıda bahsi geçen sorunların çözümü adına çocuklar için gerekli olan kentsel mekânlardaki eksikliğin giderilmesi ve bu mekânların güvenli/farklı tehlikelerden arındırılmış alanlara dönüştürülmesiyle çözüleceğini belirtmektedir. Bahsi geçen güvenlik olgusu, sadece kentsel mekânların fiziksel tehlikelerden arındırılmasıyla ilgili değildir; aynı zamanda kentsel mekânların sosyo-psikolojik yönden güvenliğini de içermektedir. Diğer bir deyişle çocukların kentsel mekân içerisinde aktif olabilmeleri ve kendilerine ayrılan alanları daha verimli kullanabilmeleri için bu güvensizliğin ve eksikliğin giderilmesi gerekmektedir.

Bu tür haberlerin son zamanlarda sıklıkla gündeme gelmesi, araştırmaclların ilgisini kent içerisindeki çocukların varlığını irdelemeye yönlendirmiş, sorunları ortaya koyan akademik araştırmalar ve çözüm önerileri sunan raporlar eskiye göre artış göstermiştir. Konuyla ilgili çalışmaların artması, kamusal alanların kentte yaşayan herkes tarafından eşit derece kullanımına açılması ve konuya yönelik farkındalığın sağlanması adına oldukça önemli görülmektedir. Yeni medyada yayınlanan haberlerde "kentsel mekân ve çocuk ilişkisini" doğrudan ortaya koyan söylemleri irdelemek isteyen araştırmacılar, yapacakları çalışmalarda şu üç öneriyi dikkate alabilir ve çalışmalarının kapsamını genişletebilir:

- Yeni medya haberciliğinde sadece yazılı basın değil; görsel-işitsel basın da kapsama dâhil edilerek araştırma genişletebilir.

- Zamansal süreç, 1 ay yerine daha uzun süreye çıkarılabilir.

- Bu çalışma kapsamında ele alınan kategoriler de genişletilebilir ve daha detaylı ele alınabilir. 


\section{EXTENDED ABSTRACT}

\section{Urban Space and Child in New Media News \\ Zehra Kurt \\ Hatay Mustafa Kemal University}

Urban space is the place that people use to meet their different needs and motivations in daily life, but it is also considered as the areas where socialization / socialization takes place. In order for people of all age groups to use urban spaces safely and efficiently, some basic analysis should be paid attention. For example, the "urban right" analysis of Henri Lefebvre is one of them. According to Lefebvre, the right to use urban space belongs to everyone living in the city, not to a specific economic-political group. The majority of the age groups using urban space are children.

With the phenomenon of rapid urbanization, the presence of children in the city is beginning to change. Urban spaces transformed with concepts such as "modernization, westernization and capitalism" are changing formally and ignoring children. Instead of going to different places, socializing, and being aware of what is happening around them, children grow / live by spending time in the home. Parents display an attitude and attitude towards spending time in their child's "safe" areas. In addition to the search for security, the families' desire for conformist life, in many studies, "Is there a living space for children in the city?" raises the question.

The relationship between urban space and children has recently been a subject of interest for such reasons and different researches have been made on it. Especially in the Convention on the Rights of the Child, signed by the United Nations, the existence of items belonging to the child's "right to life, development and participation in social life" is one of the factors that makes this matter important. It seems possible that the child can live safely and interact with the society by improving the possibilities of using urban space. It is known that children should be a part of the city and this is only possible by meeting their needs / expectations. Although the number of studies examining the relationship between urban space and children has increased, the problematic of revealing the demands and expectations of children on the city 
or to what extent these expectations have been met has not yet been overcome. The main subject of the study is based on this problem. New media journalism is one of the areas where data on the problems of urban space and children can be analyzed.

New media journalism is a digital journalism field that differs from traditional journalism with its features such as text, sound, image, and interaction, massification and being asynchronous. The most important feature of this new media journalism, which covers areas such as internet newspapers, news sites, news portals, is that it can reflect many situations / events occurring in daily life in the society. Because the new media communicate the relations existing in the social structure and define the problems / problems related to the subject. Almost every area of everyday life can be represented in new media and / or new media journalism. The topics represented in the new media news can be evaluated in different ways, and economic-political and sociocultural clues can be obtained.

In recent studies, it is seen that there are some studies on the media / new media putting the child in the foreground. For example, "child-friendly media order" is one of them. Creating a child-friendly media system is important in order to prioritize children's rights and protect them from abuse / exploitation. A child-friendly media organization depends on the establishment of a child-attended communication environment, which recognizes that children can have their own agendas like adults. There is a need for a new media that explores the issues on the agenda of children, rather than the journalistic understanding of children only when their rights are violated. In this respect, it is important that the content of the sites established for children is produced with an understanding that makes children focus.

Accordingly, the relationship of the child with the urban space is described in the new media news within the scope of the study. The aim of the study is to examine the discourses on the "relationship between urban space and children" in new media news. The data obtained is important both to point out important points to the city officials who are influential in the creation/ design of urban spaces, and to provide information that can be a starting point for researchers who want to work on the subject. The findings of the study provide urban space designers and city managers with important clues on the subject and offer a different perspective to researchers who want to work on this topic. 
This study, which deals with the discourses about the relationship between urban space and children in the news published in the new media, consists of five chapters. In the first part of the study, the relationship between the concepts of city, urban space and child was tried to be defined. In this context, in this section, it is revealed how the related concepts are related in the study. As the study aims to show the relationship between urban space and children through new media reporting, the second part is devoted to the news published in the new media. In the second part of the study, how the child is represented / related with the new media news is also examined. In the third section, methodology information is given and the method of the study is presented.

In the study, it was deemed appropriate to use the "critical discourse analysis" method, as the "relation between urban space and children" was examined in the news texts and the semantic / textual and socio-political relations related to the subject were included. Critical discourse analysis is a method that reveals deeper meanings by analyzing verbal and literary texts based on the elements in the text. Within the scope of the study, the first five sites that are among the news media sites between 1 June and 1 July 2019 were analyzed. Findings and comments from the news sites analyzed are presented in the fourth section. The study was completed with a concluding text containing the general evaluation and recommendations section.

\section{Kaynakça / References}

Akca, E. (2009). İdeoloji-dil-söylem ve anlam ilişkisi: Medyada anlamın toplumsal inşası. İ. Parlak (ed.). Medyada Gerçekliğin İnşası. Konya: Çizgi Kitapevi Yayınları.

Akdağ, Ç. T. (2016). Yeni medyada çocuk haberciliği: “Milliyet Çocuk”, “Hürriyet Çocuk" ve "Cicicee Çocuk Deyince" sayfalarının incelenmesi. Illeti-ş-im Dergisi, 25, 155-180.

Arslan, H. (2019). Eleştirel medya okuryazarlığı kapsamında çocuğa ve kadına yönelik olarak önerilen özel haber dili. Erciyes İletişim Dergisi, 6(1), 111136.

Atalay, G. E. (2019). Sosyal medya ve çocuk: "Babishko Family Fun TV" isimli youtube kanalının eleştirel bir analizi. Erciyes İletişim Dergisi, 1, 179-202.

Ballatore, A. ve Natale, S. (2005). E-Readers and The death of the book: Or, new media and the myth of the disappearing medium, Sage Publications, 1-16. 
Bucher, H. J. ve Schumacher, P. (2016). Haber içeriği seçiminde dikkatin önemibasılı ve çevrimiçi medyanın alınlanmasında dikkat örüntüleri üzerine bir göz-takip çalışması. H. Hülür ve C. Yaşın (ed.). Yeni Medya Kullanıının Yükselişi. içinde (s.221-245) .Ankara: Ütopya Yayınevi.

Bulck, J. V. Custers, K. ve Nelissen, S. (2016). The child-effect in the new media environment: challenges and opportunities for communication research, Routledge, 10(1), s.30-38.

Churchman, A. (2003). Is there a place for children in the city?, Journal of Urban Design, 8(2), 99-111.

Fairclough, N. ve Graham, P. (2003). Eleştirel söylem çözümlemecisi olarak Marx: Eleştirel yöntemin yaratılışı ve küresel sermayenin eleştirisi ile bağıntısı. Söylem ve İdeoloji, Su Yayınları.

Gibson, M., McArdle, F. ve Hatcher, C. (2015). Governing child care in neoliberaltimes: Discursive constructions of children as economic units and early childhood educators as investment brokers. Global Studies of Childhood, 5(3), 322-332.

Gür, T. (2013). Post-modern bir araştırma yöntemi olarak söylem çözümlemesi. Zeitschrift für die Welt der Türken/ Journal of World of Turks, 5(1), 185-202.

Hülür, H. ve Yaşın, C. (2017). Yeni Medya ve gazeteciliğin geleceğini çerçevelemek. H. Hülür ve C Yaşın (ed.). Yeni Medya Geleceğin Gazeteciliği. Içinde (s. 9-39), Ankara: Ütopya Yayınevi, .

Kalsın, B. (2016). Habercilikte dijital videonun yükselişi ile birlikte ortaya çıkan yöntemler ve 'Vice News' Modeli. M. G. Genel (ed.). Yeni Medya Araştırmalar 2. Içinde (s.199-219) Bursa: Ekin Yayınevi..

Keleş, R. (2005). Kent ve kültür üzerine. Mülkiye Dergisi, 29(246), 9-18.

Kılınç, B. ve Kılınç, E. P. (2018). Yeni medya ortamında çocuk birey: yeni iletişim teknolojileri ve medya pedagojisinin önemi. Akdeniz İletişim Dergisi, 22, 9-23.

Kürkçü, D. D. (2016). Yeni medya ve gençlik. İstanbul: Kriter Yayınevi.

Lefebvre, H. (2016). Şehir Hakkı. I. Ergüden (Çev.), İstanbul: Sel Yayıncılık.

Lucio, J. ve I'Anson, J. (2015). Children as members of a community: citizenship, participation and educational development:An İntroduction to The Special İssue. Eurupean Educational Research Journal. 14(2),129-137.

Manovich, L. (2018). Alan Kay ve evrensel medya makinesi. (Çev: C. Akın), F. Aydoğan (ed.). Yeni Medya Kuramcılarından Yeni Medya Kuramları içinde (s.47-70) İstanbul: Der Yayınları..

Mora, N. (2008). Medya çalı̧maları medya pedagojisi ve küresel iletişim. Ankara: Nobel Yayıncilik. 
Özdemir, E. (2010). Kentin tanımlanmasında sosyolojik yaklaşımlar: Toplumsal süreç ve/veya mekânın çözümlenmesi. İdealkent, 1, 44-77.

Özer, Ö. (2011). Haber söylem ideoloji: Eleştirel haber çözümlemeleri. Konya: Literatürk Academia Yayınları.

Şirin, M. R. (2018). Çocuk hakları ve medya üzerine.Çocukve Medeniyet Dergisi, 1,5-10. TDK (t.y) Sözlük. 20.07.2019 tarihinde http://sozluk.gov.tr/ adresinden erişilmiştir.

Tonucci, F. (2005). Citizen child: Play as Welfare parameter for urban life. Sage Pucblications, 24, 183-195.

Topal, A. (2004). Kavramsal olarak kent nedir ve Türkiye'de kent neresidir?. Dokuz Eylül Üniversitesi Sosyal Bilimler Enstitüsü Dergisi, 6(1),276-294.

Tunçer, P. (2015). Türkiye'de kentleşme politikaları, The Journal of Academic Social Science Studies, 37, 275-290.

UNICEF(2004). Cocuk Haklarina Dair Sozlesme. 20.07.2019 tarihinde https://www.unicefturk.org/public/uploads/files/UNICEF CocukHaklarinaDairSozlesme.pdf adresinden erişilmiştir.

Van Der Haak, B., Parks, M. ve Castells, M. (2017). Gazeteciliğin geleceği: A tabanlı gazetecilik. H. Hülür ve C. Yaşın (ed.). Yeni Medya Geleceğgin Gazeteciliği. Içinde (s. 67-88) .Ankara: Ütopya Yayınevi,

Wodak, R. ve Meyer, M. (2001). Critical discourse studies: History, agenda, theory and methodology. R. Wodak ve M. Meyer (ed.). Methods of Critical Discourse Analysis. Londra: Sage Publication, 1-22.

Yao, S., Isami, K. ve Huiqing (2007). Children's Play Environment Growing up in Urban Residential District of China. Proceedings of the 6th Conference of the Pacific Rim Community Design Network, 18-21.

\section{Kaynakça Bilgisi / Citation Information}

Kurt, Z. (2020). Yeni medya haberlerinde kentsel mekân ve çocuk. OPUSUluslararası Toplum Araştırmaları Dergisi, 15(25), 3753-3778. DOI: 10.26466/opus.666726 